\title{
CONTENT AGGREGATOR: PROBLEM ETIS JURNALISME ONLINE DI INDONESIA
}

\author{
Prilani \\ Program Studi Komunikasi Penyiaran Islam - STAIN Kediri \\ duta86@yahoo.com
}

\begin{abstract}
The rapid development of information and communication technology has led to the problem of journalism in Indonesia. Existing codes of ethics and rules seem to be just a scientific ornament in the practice of journalism. The appreciation for journalistic work is fading when there is a portal/web collecting other news to be aired again. Content aggregator as news gathering becomes a serious phenomenon for the continuity of journalism production. Collecting news and producing journalistic writings without media permission has been considered a custom. Yet ethically they are faced with the fact that producing credible news can't be done easily. Ethical issues in the context of Content Aggregator are divided into two sections; Presentation of news and news gathering, so it is necessary to approach ethical level for media industry as perpetrator, that is; Meta-ethics, Normative Ethics and Applied Ethics that organize media practitioners to apply journalism properly. This ethical problem can actually be anticipated through strict regulation of the opening of web/portal collecting news in vain. The logical consequence of information technology changes containing news from others is feared to undermine the grip of journalism so that the creation and enactment of media convergence legislation is a must.
\end{abstract}

Keywords: Content Aggregator, Ethical Problems, Online Journalism

\begin{abstract}
Abstrak
Perkembangan teknologi komunikasi yang semakin melesat telah membawa pada persoalan jurnalisme di Indonesia. Kode etik dan aturan yang telah ada seakan hanya menjadi hiasan ilmiah dalam praktek jurnalisme. Penghargaan terhadap karya jurnalistik menjadi memudar ketika terdapat portal/web mengumpulkan berita lain untuk ditayangkan kembali. Content Agregator sebagai pengumpulan berita menjadi fenomena serius bagi kelangsungan produksi jurnalisme. Pengumpulan berita dalam tanpa seizin media atau jurnalis yang memproduksi telah dianggap sebagai kelaziman. Padahal secara etika mereka dihadapkan pada kenyataan bahwa memproduksi berita yang kredibel tidak bisa dikerjakan dengan mudah. Persoalan etika dalam konteks Content Aggregator dibagi menjadi 2 bagian; penyajian berita dan pengumpulan berita, sehingga perlu pendekatan level etika bagi industri media sebagai pelaku, yakni ; Meta-etika, Etika Normatif dan Etika Terapan yang mengatur praktisi media untuk menerapkan jurnalisme secara benar. Problem etis ini sebenarnya bisa diantisipasi melalui regulasi yang ketat terhadap pembukaan web/portal yang mengumpulkan berita secara sembarangan. Konsekuensi logis perubahan teknologi informasi yang memuat berita dari orang
\end{abstract}


lain dikhawatirkan merusak pakem jurnalisme sehingga pembuatan dan pemberlakuan undangundang konvergensi media menjadi suatu keharusan.

Kata Kunci; Content Aggregator, Problem Etis, Jurnalisme Online

\section{PENDAHULUAN}

Perkembangan jurnalisme menjadi luar biasa ketika teknologi komunikasi mengalami perubahan secara cepat. Jurnalisme hari ini terasa sangat mendominasi informasi dengan adanya konvergensi media untuk mendistribusikan produk informasi yang dihasilkannya. Disisi lain, dunia jurnalisme sekarang ini telah mengalami gejolak perkembangan yang masih abu-abu. Konteks abu-abu ini dikarenakan bahwa sebagian orang memandang bahwa produk jurnalisme belum dapat dipercaya secara utuh dan sebagian lagi memilih untuk melihat keobyektifan dari berita yang dihasilkan.

Belum adanya data yang tepat tentang jumlah media massa di Indonesia juga berdampak pada bagaimana masyarakat sebagai khalayak memperoleh konten yang dihasilkan. Jika dilihat dari media yang ada sekarang, kebanyakan dari media dimiliki oleh para elit yang memiliki kepentingan politik di balik usaha media yang mereka bangun. Menurut anggota Dewan Pers, Yosep Stanley Adi Prasetyo ; Jumlah media online di Indonesia diperkirakan ada sekitar 2.000. Namun dari jumlah tersebut hanya 221 media yang memenuhi syarat disebut sebagai media profesional. (www.detik.com). Di lain pihak, ada beberapa lembaga yang memperkirakan jumlah media online (siber) di Indonesia mencapai angka 43.300, tapi angka yang tercatat masih perlu dikaji ulang karena belum ada rilis resmi dari lembaga-lembaga yang kredibel untuk memetakan media online. Persoalan ini sebenarnya lebih kepada regulasi di negara kita yang setengah hati dalam mengatur persoalan media online. Profesionalitas dalam pengelolaan media dan independensi media yang ada sekarang ini juga menjadi persoalan serius. Idealisme dalam penyajian berita yang berimbang (cover both side) oleh wartawan/jurnalis adalah dengan berusaha untuk menampilkan berita atau memberikan topik yang berimbang, tetapi jika berita tersebut sudah sampai di pihak redaktur belum tentu berita tersebut yang akan ditayangkan atau diterbitkan.

\section{TINJAUAN PUSTAKA}

Sejarah media membuktikan bahwa sebuah kemunculan teknologi baru tidak serta merta menghilangkan teknologi lama. Tapi ia mensubtitusinya sebagai bagian dari media itu sendiri. Septiawan Santana mengatakan dalam Jurnalisme Kontemporer (2005:135), radio tidak menggantikan surat kabar, namun menjadi sebuah alternatif, menciptakan sebuah kerajaan dan khalayak baru. Demikian pula dengan televisi, meskipun televisi (TV) melemahkan radio, tetap tidak dapat secara total mengeliminasinya.

Media kontemporer mungkin tidak akan bisa menggantikan sepenuhnya bentuk-bentuk media lama. Melainkan, tampaknya menciptakan suatu cara yang unik untuk memproduksi berita dan mendapatkan konsumen berita. Keprihatinan yang lain dalam produksi jurnalisme adalah masalah ekonomi, terkait dengan gaji seorang jurnalis. Minimnya gaji tersebut membuat tidak sedikit para wartawan untuk mencari pekerja 
sampingan. Misal, pilihan menjadi wartawan amplop sehingga obyektivitas suatu berita berdasarkan fakta sudah tidak lagi menjadi target bagi wartawan. Selain itu, masih ada permasalahan lain, adalah membuat berita yang tidak kredibel. Salah satu penyebabnya adalah Deadline. Jika deadline sudah ditentukan dan seorang wartawan/jurnalis tidak dapat mencari berita di lapangan, maka hal-hal seperti memanipulasi data berita pun sudah pasti dilakukan. Subjektivitas dari seorang jurnalis pun dikeluarkan dengan mengabaikan objektivitas dari sebuah berita.

Pesatnya pertumbuhan media online sebagai media kontemporer juga membuat semakin semaraknya konten dari pemberitaan media. Era konvergensi media sedikit banyak telah mewarnai konten media di Indonesia. Sejumlah media, seperti ; Kompas, MNC Group, Media Group dan Trans Corp adalah contoh media yang selalu mengikuti perkembangan teknologi. Produksi informasi yang selama ini hanya dipasarkan secara konvensional sekarang telah bergeser sampai pada penggunaan media lain sebagai sarana distribusi. Hal ini lah yang mendasari bergesernya logika jurnalisme konvensional menjadi jurnalisme online. Jurnalisme Online sebagai produk media kontemporer di era New Media menurut James C. Foust (Dalam Romli ; 2012:16) memiliki beberapa tujuh ciri antara lain : (1) Audience Control yang memungkinkan pembaca lebih leluasa memilih berita/informasi; (2) Non-Linearity yang berarti masing-masing berita berdiri sendiri sehingga pembaca tidak harus membaca secara berurutan ; (3) Storage and Retrieval yang memungkinkan berita dapat disimpan, diakses kembali kapan dan dari mana saja; (4) Unlimited Space memungkinkan halaman tak terbatas akibat dari tidak terbatasnya ruang sehinngga sebuah artikel dan berita bisa dipaparkan secara rinci dan detil ; (5) Immediacy kemampuan untuk dapat menyampaikan berita secara cepat dan langsung saat peristiwa terjadi ; (6) Multimedia Capability kemampuan untuk menyajikan berita dalam bentuk teks, suara, gambar, video, dan komponen lainnya sekaligus; (7) Interactivity yang memungkinkan interaksi langsung antara redaksi dengan pembaca, seperti melalui kolom komentar dan social media sharing.

Karakteristik di atas menunjukan betapa jurnalisme online sebagai bentuk media kontemporer telah bergeser mulai dari proses sampai kepada distribusi. Tanggal 17 Januari 1998 disebut-sebut sebagai tonggak sejarah kelahiran juranalisme online, yaitu ketika Mark Druge, berbekal sebuah laptop dan modem, mempublikasikan kisah perselingkuhan Presiden Amerika Serikat, Bill Clinton, dengan sekretarisnya Monica Lewinsky (Monicagate) di website Druge Report, setelah majalah Newsweek dikabarkan menolak memuat kisah skandal seks hasil investigasi Michael Isikoff. Semua orang yang mengakses internet segera mengetahui rincian cerita Monicagate yang juga di kenal "Monica Scandal" dan "Sexgate". (M.Romli, 2012-19). Realitas inilah yang menginspirasi kekuatan baru terkait dengan jurnalisme yakni jurnalisme online.

\section{HASIL DAN PEMBAHASAN}

Perkembangan jurnalistik online di Indonesia mulai berkembang pada tahun 1998. Kemunculan dan perkembangan jurnalistik online ini ditandai dengan berita menggegerkan, yaitu berakhirnya era pemerintahan Orde Baru saat Soeharto 
mengundurkan diri pada 21 Mei 1998. Berita pengunduran diri Soeharto tersebar luas melalui milist (mailing list) yang sudah dikenal luas di kalangan aktivis demokrasi dan mahasiswa. (M.Romli, 2012-20). Distribusi informasi semacam ini tergolong kategori media baru dan tidak semua orang bisa mengakses produk informasi ini secara mudah pada saat itu. Selain akses internet yang terbatas juga pengetahuan masyarakat tidak seperti sekarang, sehingga pola konsumsi media pada saat itu sangat terbatas.

Pada awalnya konten dalam media online dan media cetak (Kompas dan Republika) sama secara tampilan sehingga tidak memiliki perbedaan antara kedua media tersebut. Produk media cetak hanya dipindahkan dalam media online sehingga kontennya sama persis. Selanjutnya, ada media online yang serius untuk menyajikan berita melalui media online yaitu detik.com yang muncul pada tahun 1998 dengan menyajikan berita real time. Detik.com berbeda dengan media lain yang hanya memindahkan konten yang ada dalam media cetak dalam bentuk online. Detik.com pernah membuat media cetak namun tidak bertahan lama dan sampai saat ini detik.com hanya fokus pada media online. Informasi yang dimuat dalam detik.com juga selalu up to date. Lima tahun kemudian, setelah detik.com yang fokus membangun media online sebagai media jurnalistik, muncul media-media cetak lain mulai membuat surat kabar dalam bentuk online.

Seiring dengan perkembangan internet di Indonesia tahun 2007, diprediksi akan banyak bermunculan media-media online yang real time. Hingga akhirnya, media online mulai menjadi rujukan utama masyarakat dalam mencari informasi. Kemudahan mengakses internet telah memberikan banyak dampak positif. Perkembangan teknologi membawa telah membawa perubahan pesat dan membuat semua menjadi lebih praktis.

Persoalan muncul ketika media online ini menyajikan berita yang terkadang tidak jelas sumbernya dan lebih parahnya lagi digunakan oleh media lain sebagai rujukan. Problem inilah yang sangat urgent untuk menjadi perhatian semua pihak, karena efek dari proses jurnalisme seperti ini akan semakin memperparah ketidakpercayaan masyarakat kepada media. Kecanggihan teknologi untuk memudahkan produksi jurnalistik bisa menjadi sebaliknya, membuat berita tidak pada posisi mencerahkan masyarakat.

Fenomena di atas hanya sebagaian problem tentang jurnalisme kontemporer, masih ada problem krusial terkait dengan pola distribusi informasi portal/web yang sering disebut Content Aggregator. Pola ini mengundang keprihatinan beberapa pihak terutama yang merasa dirugikan akibat hasil dari produksi mereka digunakan oleh media online lain ataupun portal/web yang sengaja hanya mengumpulkan berita dari orang lain. Dari sisi etika memang muncul pertanyaan karena proses produksi berita tidak saja mudah tetapi juga melalui perjuangan jurnalis dilapangan.

\section{Content Aggregator}

Berbagai macam definisi tentang Content Aggregator telah membawa dampak pada prespektif masing-masing. Ilmuan Komunikasi, Ekonomi, Tehnik dan Ilmu yang lain membuat tafsir dalam kaca mata keilmuannya. Prespektif Media mendefinisikan Content Aggregator sebagai individu atau organisasi yang mengumpulkan konten Web (dan/atau kadang-kadang aplikasi) dari sumber online 
yang berbeda untuk digunakan kembali atau dijual kembali. Ada dua jenis Content Aggregator : (1) mereka yang hanya mengumpulkan materi dari berbagai sumber untuk situs Web mereka, dan (2) orang-orang yang mengumpulkan dan mendistribusikan konten yang sesuai dengan kebutuhan pelanggan mereka. Proses terakhir ini disebut sindikasi. Screaming Media dan iSyndicate dapat meningkatkan jumlah perusahaan yang menawarkan konten untuk dijual kembali. (http://searchcontentmanagement.techtarg et.com)

Persoalan Content Aggregator dirasakan kurang mendapat perhatian serius dari penggelola media. Hal ini di dasarkan bahwa proses penayangan berita ini tidak melalui produksi sendiri, melainkan hanya mengumpulkan. Dan masalah muncul ketika mereka mendulang keuntungan dari iklan terkait dengan pengumpulan berita ini tanpa mempertimbangkan jurnalis yang memproduksi konten sebelumnya. Secara sederhana, Content Aggregator adalah situs yang mengepul aneka informasi dari berbagai situs lain seperti apa yang dilakukan oleh Yahoo dan Google. (Kristanto, dalam Margianto, 2012:46).

Plagiasi konten dapat dilakukan dengan menjelajahi internet untuk memperoleh konten yang berharga dan dibagikan kepada komunitas sosial mereka. Apa yang dilakukan oleh Yahoo dan Google merupakan bukti bagaimana sumber konten dapat disajikan kepada khalayak dengan cara baru yang lebih menarik. Dimensi baru berita ini dapat di lihat pada gambar di bawah ini ;

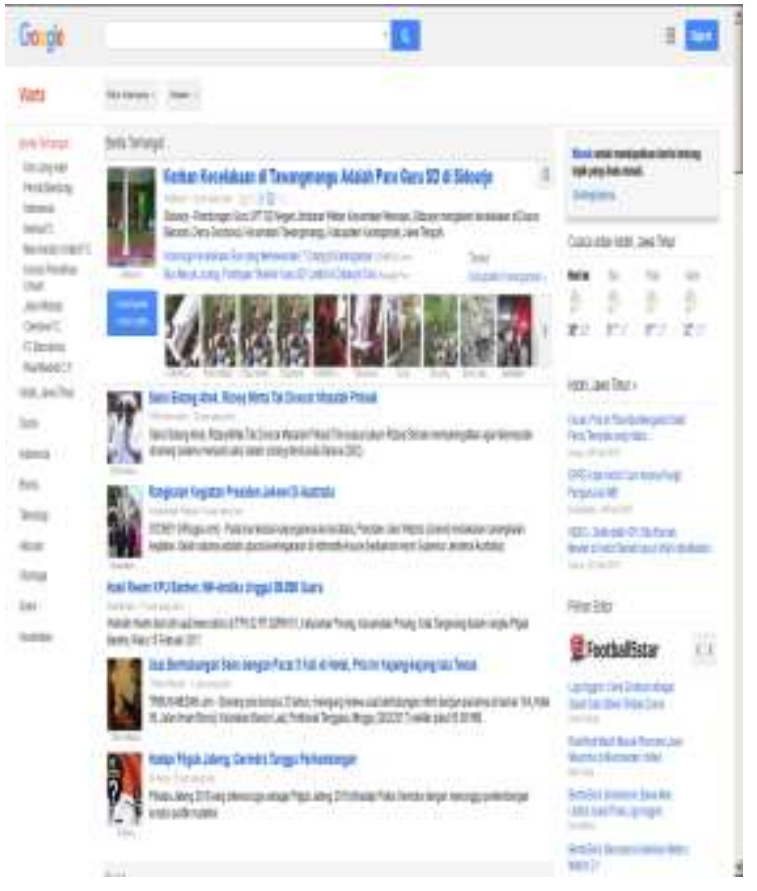

Gambar : temuan konten dalam google

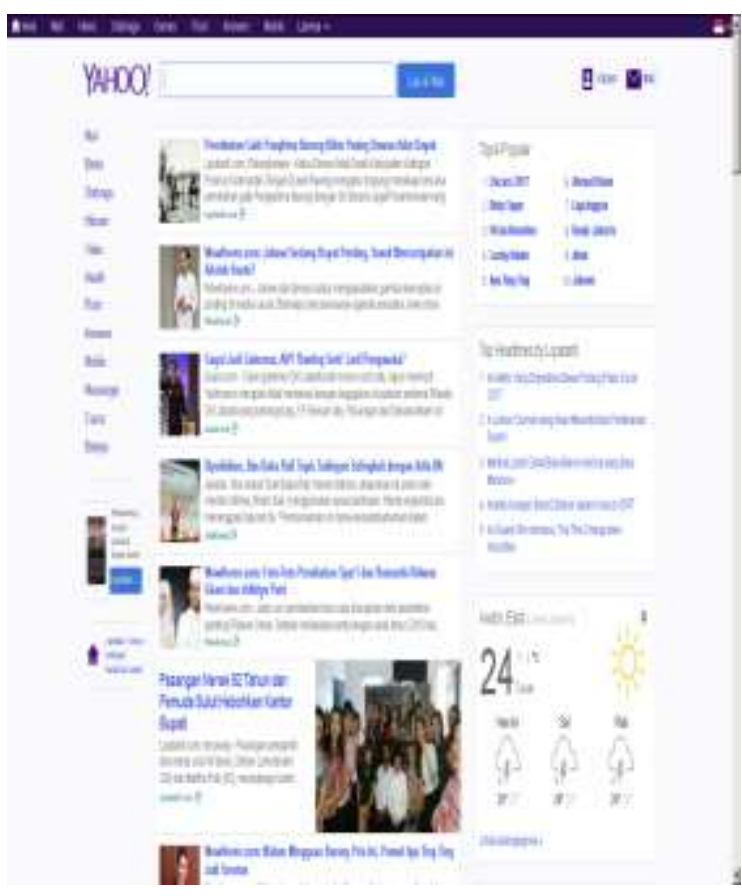

Gambar : temuan konten dalam yahoo

Gambar di atas menunjukan bahwa Google dan Yahoo secara massif mengumpulkan berita-berita dari sumber lain dan siapa saja bisa mengakses secara gratis. Proses inilah yang dianggap sebagai 
Content Agregator dan berpotensi melanggar kode etik jurnalistik yang sebenarnya harus dipatuhi oleh manajemen media yang mengelola media online. Menurut Rupert Murdock, seharusnya Google dan Yahoo membayar setiap berita yang di comot dari sebuah media. Hal ini untuk menghindari konflik kepentingan antara media yang memproduksi konten dengan media yang hanya menayangkan sebuah berita. (Kristanto, dalam Margianto, 2012:46).

Persoalan muncul ketika akurasi Content Agregator kurang memadai dalam penyampaian berita karena bisa saja tidak ada klarifikasi bahkan berita hoax. Konten yang dapat membingungkan adalah agregasi konten dengan sindikasi konten orang lain dan sering ditemukan dari berbagai portal. Disisi lain, proses ini menciptakan dan menerbitkan konten yang telah diproduksi oleh media dengan menggabungkan beberapa konten sebagai bagian dari kurasi konten atau sebagai proses riview dan penggabungan.

Perbedaan antara agregasi konten dan kurasi konten ini lebih kepada persoalan bagaimana portal secara otomatis mengumpulkan informasi berdasarkan kata kunci. Sedangkan, kurasi pada dasarnya bersifat manual dan ini dianggap sesuatu yang paling dominan membahayakan jika tidak ada filter yang memadai karena pesan yang ditampilkan oleh berita secara otomatis dapat diakses oleh siapapun.

Pencarian berita secara manual di internet lebih mudah dilakukan akan tetapi bisa lebih sulit untuk mengklarifikasinya. Siapapun bisa mengambil artikel orang lain dan menggunakannya dalam portal yang digunakannya sehingga konten tidak benarbenar memberikan sesuatu yang baru kepada pembaca. Problem etis ini harus dipikirkan oleh penggelola media online untuk dapat menjunjung tinggi kode etik jurnalistik dalam prespektif teknologi komunikasi.

Khalayak sebagai pembaca akan mengalami titik kejenuhan karena dominasi berlebihan dari berita-berita Content Agregator. Google maupun Yahoo mungkin berpikir memanfaatkan peluang terbaik, karena konsep marketing bisa dioptimalkan melalui proses ini. Padahal sebenarnya, mereka bisa menggali berita lebih mendalam dan mengungkapkan keseluruhan realitas tanpa dominasi opini yang berlebihan dari proses pengumpulan berita.

\section{Etika dalam Jurnalisme Online}

Kemunculan digital, komputer, atau jaringan teknologi informasi dan komunikasi sebagai media baru format digital, seringkali memiliki karakteristik dapat dimanipulasi, bersifat jaringan, padat, mampat, interaktif dan tidak memihak. Secara sederhana media online adalah media yang terbentuk dari interaksi antara manusia dengan komputer dan internet secara khususnya. Termasuk di dalamnya adalah web, blog, online social network, online forum dan lain-lain yang menggunakan komputer sebagai medianya.

Jurnalis-jurnalis yang masih punya komitmen dalam meletakan kode jurnalistik dapat diapresiasi dengan menegakkan independensi untuk menyajikan berita kepada masyarakat. Ketaatan pada hukum atau pada kode etik professional tidak selalu melahirkan tindakan moral. Etika adalah persoalan individual yang berhubungan dengan kesadaran (Vivian,2008:632-633).

Penggunaan berita untuk dikumpulkan dalam sebuah portal/web jelas tidak sesuai dengan etika media karena mereka tidak memproduksi sendiri 
konten yang akan di unggah dalam portal/web. Merujuk pada beberapa kaidah hukum, persoalan ini sebenarnya bisa di proses melalui proses persidangan. Namum, payung hukum yang ada belum tentu bisa menjembatani antara para pihak yang dirugikan maupun yang diuntungkan sehingga proses ini harus menjadi kajian mendalam tentang bagaimana mengelola media online secara komperehensif.

Untuk membantu para penulis online dalam menyajikan tulisan ataupun beritanya, Cuny Graduate School of Journalism yang didukung Knight Foundation (http://www.kcnn.org) mencatat 10 langkah utama bagi jurnalis online supaya terhindar dari masalah hukum. (1) Periksa dan periksa ulang fakta. (2) Jangan gunakan informasi tanpa sumber yang jelas. (3) Perhatikan kaidah hukum. (4) Pertimbangkan setiap pendapat. (5) Utarakan rahasia secara selektif. (6) Hatihati terhadap apa yang diutarakan. (7) Pelajari batas daya ingat. (8) Jangan lakukan pelecehan. (9) Hindari konflik kepentingan. (10) Peduli nasehat hukum.

Langkah-langkah di atas setidaknya dapat menjadi acuan. Fakta telah membuktikan bahwa keakurasian berita bisa menjadi montir hebat produk jurnalistik selain aspek hukum lain yang mengikat. Penjabaran dari realitas yang dibawa dalam bentuk tulisan sedapat mungkin menghidari konflik kepentingan, baik itu pengusaha media, jurnalis maupun audiens.

Nicholas Johnson, mantan Komisioner Komisi Komunikasi Amerika Serikat (AS) (dalam Priyambodo, 2007) memberikan catatan bahwa ada hal mendasar menyangkut kasus jurnalisme. Beberapa diantaranya adalah (1) Menyerang kepentingan individu, pencemaran nama baik, dan pembunuhan karakter/reputasi seseorang,

menyebarkan kebencian, rasialis, dan mempertentangkan ajaran agama, (3) menyebarkan hal-hal tidak bermoral, mengabaikan kaidah kepatutan menyangkut seksual yang menyinggung perasaan umum, dan perundungan seksual terhadap anakanak, (4) menerapkan kecurangan dan tidak jujur, termasuk menyampaikan promosi/iklan palsu, (5) melanggar dan mengabaikan hak cipta (copyright) dan Hak Atas Karya Intelektual (HAKI, atau Intelectual Property Right/IPR).

Catatan-catatan di atas tentunya tidak sesuai dengan apa yang ada dalam proses Content Aggregator sebagai bagian dari jurnalisme kontemporer. Menurut Online Jurnalism Review yang dikeluarkan oleh Annenberg School of Journalism, University of Southern California (http://www.ojr.org/ojr/wiki/Ethics).

Sebuah tulisan yang sudah di-posting dalam situs online ataupun blog, sudah bukan lagi menjadi sebuah tulisan biasa melainkan merupakan informasi yang dapat menjadi referensi bagi pembacanya. Oleh karena itu, sebaiknya pembaca tidak sembarangan dalam menulis karena belum ada undang-undang khusus yang berbicara mengenai jurnalisme online ini.

Persoalan etika yang muncul dalam konteks Content Aggregator setidaknya dapat dikelompokkan menjadi dua hal sebagai berikut. Pertama, berkaitan dengan penyajian berita media online. Para jurnalis menghadapi kondisi yang membutuhkan pertimbangan etis terkait dengan media online mulai dari kegiatan dilapangan untuk merekam dan mengutip serta membuat berita sampai penayangan berita secara online. Di sisi lain, internet meningkatkan intensitas kompetisi antar media untuk menjadi yang pertama dalam 
hal pelaporan berita padahal peristiwa masih berkembang dan fakta kunci belum diketahui. Selain itu, pemisahan antara kepentingan redaksi dan bisnis pada media sering menjadi kendala, misalnya redaksi menghadapi persoalan iklan dan pemilik media berpikir dalam konteks bisnis yang bisa berakibat pada kredibilitas dan independensi redaksi. Kedua, berkenaan dengan pengumpulan berita oleh content agregator. Proses inilah yang menjadi kunci persoalan antara etika dan hukum media. Kondisi ini tentunya membuat para pihak harus mendudukan pada posisinya masing-masing karena konsep mengumpulkan berita mengandung persoalan banyak hal. Akurasi berita menjadi tema penting, selain faktor etika yang seringkali diabaikan oleh pengelola media. Akurasi berita menjadi perhatian serius karena berita yang dihasilkan tidak diproduksi sendiri dan secara etika bisa menjadi catatan etika penggeloaan media atau yang sering disebut manajemen media. Mengumpulkan sekian banyak berita dalam satu portal/web tentunya memerlukan filter yang kuat terkait konten untuk meminimalisir berita hoax.

Kedua persoalan di atas setidaknya dapat membuka perhatian kita dalam menyikapi pengelolaan media yang berbasis online khususnya pelaku content aggregator. Etika industri media menjadi penting sebagai dasar menciptakan media yang kredibel sebagai penyedia informasi. Menurut Baran (2012:143) terdapat tiga level etika bagi industri media yakni: 1) Meta-etika yang merupakan nilai budaya fundamental. 2) Etika Normatif yang berupa teori, aturan dan prinsip atau perilaku moral yang kurang lebih digeneralisasikan. 3) Etika terapan yang mengatur praktisi media untuk menerapkan aturan besar maupun panduan umum pada situasi-situasi tertentu. Ketiga level ini dapat digunakan sebagai langkah antisipatif terhadap perilaku content aggregator sehingga dapat meminimalisir penyimpangan jurnalisme online.

\section{Regulasi dan Etika Media Kontemporer}

Regulasi yang terkait jurnalisme sudah banyak dikeluarkan oleh lembagalembaga negara maupun lembaga independen yang ada di Indonesia. Menilik undang-undang yang terkait dengan jurnalisme kita lihat pada UU Pers No. 40 Tahun 1999 dan UU Penyiaran No. 32 tahun 2002 sudah melihat potensi masalah dalam proses jurnalisme baik dalam konteks media cetak maupun elektronik. Hadirnya, Kode Etik Jurnalistik dan Pedoman Perilaku Penyiaran dan Standar Program Isi Siaran (P3SPS) setidaknya dapat menjadi acuan praktek jurnalistik. Persoalan muncul ketika teknologi internet digunakan sebagai alat oleh media massa sehingga aturan di atas belum maksimal dapat dijadikan acuan dalam proses jurnalistik.

Persoalan regulasi menyangkut seberapa jauh masyarakat mempunyai hak untuk mengakses media massa termasuk media sosial yang berkembang sedemikian cepat. Di sisi lain, seberapa jauh distribusi media massa dan media sosial mampu dijangkau oleh masyarakat. Problem mendasar dari regulasi jurnalisme media dalam konteks content aggregator terkait dengan seberapa jauh masyarakat mempunyai akses terhadap media dan seberapa jauh isi media dapat dianggap tidak melanggar norma yang berlaku.

Dewan Pers, telah mengeluarkan Pedoman Media Siber bagi lembaga yang sudah terverifikasi, namun bagaimana dengan media lain yang belum teridentifikasi dan secara nyata sering 
membuat opini dan berita yang tidak berimbang. Kekhawatiran sebagian kalangan bahwa isi media pada bagian tertentu akan merusak moral generasi muda merupakan salah satu poin penting yang harus dipikirkan oleh para pelaku media. Dalam hal penciptaan regulasi media kontemporer, institusi yang paling berwenang membuat regulasi adalah pemerintah atau negara. Cara pandang demikian dapat dipahami jika dilihat dari fungsi negara sebagai Regulatory Agent di dalam menjaga hubungan antara pasar dan masyarakat.

Di satu sisi negara memegang kedaulatan publik dan di sisi lain negara mempunyai aparatur yang berfungsi menjaga efektif tidaknya sebuah regulasi. Dominasi media kontemporer cenderung membuat masyarakat tidak punya pilihan lain selain menerima apa adanya tampilantampilan yang ada pada media. Dalam konteks content aggregator ini, negara belum mampu memberikan payung hukum yang memadai bagi keberlangsungan jurnalisme online. Namun di sisi lain, pada saat sebuah kebijakan disahkan dan dicoba diimplementasikan, boleh jadi telah muncul varian teknologi baru yang tak terjangkau oleh regulasi tersebut. Ini tidak berarti bahwa pembuatan regulasi tak harus dilakukan, bagaimanapun regulasi menjadi kebutuhan mendesak agar teknologi komunikasi baru sehingga tidak menjadi instrumen degradasi moral atau menjadi alat bagi kekuasaan untuk menidurkan kesadaran masyarakat sebagai khalayak. Kurangnya koordinasi antara stakeholder merupakan faktor utama penyebab regulasi kita tidak berdaya atas maraknya jurnalisme kontemporer.

Media baru dengan memanfaatkan internet telah menjadikan jaringan secara makro ke seluruh dunia. Kita dapat melihat bahwa konsumen media seperti cetak mengalami perubahan yang cukup besar setelah munculnya jurnalisme online sebagai bentuk new media. Membangun sebuah regulasi yang komprehensif dan berdimensi jangka panjang tentu saja bukan hal yang mudah. Bahkan dalam konteks perkembangan teknologi komunikasi yang makin cepat, regulasi yang berdimensi jangka panjang nampaknya hampir menjadi satu hal yang mustahil. Adagium tentang regulasi yang selalu ketinggalan dibandingkan perkembangan teknologi mesti disikapi secara bijak. Pasalnya, sebuah bangunan kebijakan selalu mengandung celah multiinterpretasi sehingga bisa saja hal itu dimanfaatkan untuk menampilkan pencitraan media.

Content aggregator merupakan konsekuensi logis dari perkembangan tehnologi terutama internet. Regulasi adalah suatu keniscayaan sebagai akibat dari fenomena ini sebagaimana yang telah dilaksanakan oleh beberapa negara. Namun penerapan regulasi tidak mudah seperti membalikan kedua tangan, diperlukan pendekatan etika sebagai acuan karena regulasi berupa aturan dan etika adalah kesadaran.

Media kontemporer yang mempunyai embrio dari produksi junalisme online secara regulasi bisa diatur melalui konteks konvergensi media. Pendekatan ini memerlukan kesadaran beberapa pihak untuk membuat dalam bingkai hukum dan menjadikan regulasi yang harus ditaati oleh pelaku media, yakni ; pemilik, jurnalis maupun masyarakat yang bisa menjadi sumber informasi. Peraturan tentang konvergensi media ini sedapatnya memuat tentang problem administrasi, teknis dan konten. Terkait content aggregator, lahirnya undang-undang konvergensi media nanti setidaknya dapat mengatur 
tentang problem etis terkait dengan pengumpulan berita yang dilakukan oleh pelaku content aggregator.

\section{PENUTUP}

\section{Kesimpulan dan Saran}

Zaman menuntut kita untuk menyesuikan dengan perkembangan terutama teknologi informasi, namun teknologi jangan digunakan untuk mempermudah segala cara. Masyarakat abad sekarang melek dengan teknologi dan membutuhkan informasi sebagai bagian dari kebutuhan hidup. Informasi sebagai produk jurnalisme setidaknya memberikan solusi bukan malah memperkeruh masalah yang terjadi dalam masyarakat.

Realitas jurnalisme selalu membawa perubahan dan cara pandang masyarakat sebagai audiens sehingga diperlukan jurnalisme yang konstruktif dan akuntabel. Jurnalisme online sebagai media kontemporer sangat tergantung kepada teknologi internet sebagai alat dan permasalahan kembali muncul setelah teknologi ini digunakan secara tidak baik bagi produk berita terlebih pada media yang mengadopsi dari produk media lain seperti apa yang dilakukan oleh pelaku content aggregator. Pengguna media informasi juga harus bisa bersikap bijak dalam menggunkan media online, agar media online bisa menjadi alternatif informasi di era digital.

Fenomena Content Agregator mengembalikan Ke-akurasian dan keoriginalitas dari konten berita sebagai tanggung jawab sosial pihak-pihak yang menjadi pelaku. Pertanggung-jawaban etis atas berita menyangkut aspek sosiologis masyarakat, diperlukan kearifan semua pihak untuk secara bersama-sama menangulangi fenomena ini. Negara harus menfasilitasi fenomena ini dengan produk undang-undang yang mengakomodir semua kepentingan dalam media kontemporer.

\section{DAFTAR PUSTAKA}

Baran, Stanley. J. 2012. Pengantar Komunikasi Massa: Melek Media \& Budaya (Jilid 2 Edisi 5). Jakarta: Penerbit Erlangga.

M. Romli, Asep Syamsul. 2012. Jurnalistik Online. Bandung. Nuansa Cendekia.

Margianto, J. Heru \& Asep Syaefullah, 2012. Media Online: Pembaca, Laba dan Etika (Problem Praktik Jurnalisme Online di Indonesia). AJI Indonesia. Ford Foundation.

Priyambodo, RH (06/05/2008) "RanjauRanjau dan Kode Etik Jurnalis Online", makalah pada Lokakarya Kode Etik Jurnalistik untuk Praktisi Media di Lembaga Pers Dr. Soetomo/LPDS dan Dewan Pers, Jakarta

Santana, Septiawan. 2005. Jurnalistik Kontemporer. Jakarta: Yayasan Obor Indonesia.

Vivian, Jhon. 2008. Teori Komunikasi Massa. Edisi Kedelapan. Jakarta: Kencana Prenada Media Group.

\section{Referensi Online:}

https://id.yahoo.com di akses tanggal 1 April 2017

https://news.google.co.id di akses tanggal 1 April 2017

http://www.detik.com di akses tanggal 9 April 2017

http://www.kcnn.org di akses tanggal 12 April 2017

http://www.aji.or.id di akses tanggal 14 April 2017

http://www.dewanpers.or.id di akses tanggal 17 April 2017 
http://searchcontentmanagement.techtarget

.com di akses tanggal 21 April 2017

http://www.ojr.org/ojr/wiki/Ethics di akses

tanggal 29 April 2017 